\title{
Pecan Production in the Northem United States
}

William Reid ${ }^{1}$ and Kenneth L. H unt ${ }^{2}$

Additional INDEX wORds. Carya illinoinensis, pecan cultivars, native pecans

Summary. More than $93 \%$ of pecans [Carya illinoinensis (Wangenh.) K. Koch] produced in the $\mathrm{U}$ nited States are grown in the southeastern and southwestern states. $\mathrm{H}$ owever, the native range of the pecan tree extends northward into Kansas, M issouri, and Illinois. In these northern states, commercial pecan production is expanding as additional acres of native trees are brought under cultivation and orchards of short-season, cold-hardy cultivars are established. N ative nut production dominates the northern pecan industry accounting for over $95 \%$ of nuts produced in the region. Cultural practices for native pecans have been developed for northern groves that feature low inputs and good yields. Pecan cultivars adapted to the north ripen their fruit in a climate that provides 155 to 200 frost-free days. Few generalizations can be made about northern cultivars. The nuts produced by these cultivars vary in size from small $[4 \mathrm{~g}(0.14 \mathrm{oz})]$ to medium [ $8 \mathrm{~g}$ $(0.28 \mathrm{oz})$ ] with shelling percentages ranging from $44 \%$ to $59 \%$

$\mathrm{P}$

ecan (Carya illinoinensis) is widely recognized as a nut crop that thrives in the warm, long, growing season of the southern

U nited States. Today, the states of Georgia, Alabama, L ouisiana, Texas, O klahoma, N ew M exico, and Arizona produce more that 93\% of the nation's commercial pecan crop ( $\mathrm{N}$ ational Agricultural Statistics Service, 1999). H owever, the natural range of this indigenous nut tree extends well north of the M ason-D ixon line (Peterson, 1990). $N$ atural stands of seedling pecan trees occur in Kansas, M issouri, I owa, Illinois, and I ndiana. G rowing in the floodplains of major midwestern rivers and their tributaries, northern native pecans are well adapted to the relatively short growing season and cold winter temperatures. A small, but expanding, pecan industry has emerged in northern states based on the harvest of nuts from native trees and from culture of shortseason, cold-hardy pecan cultivars.

\section{Culture of northern native pecans}

O ver $95 \%$ of nuts produced in northern pecan states are harvested from natural stands (Reid and Eikenbary, 1991). N ut-producing groves have been carved from riparian forests by removing all competing tree species and managing the remaining and pecan trees.

Contribution no. 00-47-J from the Kansas Agricultural Experiment Station. The cost of publishing this paper was defrayed in part by the payment of page charges. U nder postal regulations, this paper therefore must be hereby marked advertisement solely to indicate this fact.

${ }^{1}$ Associate professor, Pecan Experiment Field, Kansas State U niversity, Chetopa, KS 67336-0247.

${ }^{2} \mathrm{PhD}$ fellow, School of N atural Resources, U niversity of M issouri, Columbia, M O 65211. 
Table 1. Prices paid for native pecans grown in selected states from 1996-98 (N ational Agricultural Statistics Service, 1999) $(\$ 1.00 / \mathrm{lb}=\$ 2.20 / \mathrm{kg})$.

\begin{tabular}{lccc}
\hline & \multicolumn{3}{c}{ Price $\mathbf{( \$ / \mathbf { l b } )}$} \\
\cline { 2 - 4 } State & $\mathbf{1 9 9 6}$ & $\mathbf{1 9 9 7}$ & $\mathbf{1 9 9 8}$ \\
\hline Kansas & 0.98 & 0.67 & 0.88 \\
Louisiana & 0.40 & 0.48 & 0.60 \\
Oklahoma & 0.52 & 0.55 & 0.68 \\
Texas & 0.50 & 0.48 & 0.85 \\
\hline
\end{tabular}

The creation of a productive native pecan grove is a five-step process: thinning trees, improving surfacedrainage, fertilizing, controlling key pests, and managing the groundcover (Reid and O Icott-R eid, 1985).

Tree thinning is the primary cultural practice utilized to enhance nut production from native stands. Proper treespacing allowslight to penetratethe canopy, stimulating fruit production throughout the entire tree ( $\mathrm{H}$ inrichs, 1958). In addition, ample space between trees improves air circulation in thegroveto provideamicroclimatethat slows plant disease development. T rees that are diseased, susceptible to key pests, unproductive, highly alternate bearing, or those producing extremely small nuts are removed during the thinning process. Thisjudicious removal of inferior trees produces native groves with higher yields, low alternate bearing, and higher nut quality. Sales of wood products produced during grove creation provide landowners with significant income over and above the costsof treeand stump removal (Shreve, 1993).

Growing in the floodplains of major rivers, native pecan trees frequently aresubjected to seasonal flooding (R eid, 1995). Although pecan is quite flood tolerant, persistent pools of standing water in the grove can cause nitrogen deficiency (viadenitrification) and noninfectious leaf scorch (Reid, 1999a). Improving surface drainage helps reduce these physiological maladiesand is an essential prerequisite for cost-effective application of nitrogen to the soil.

Thealluvial soilsthat support stands of native pecan in northern states are typically fine-textured, fertile, and somewhat poorly drained. Pecan trees would perform better on sandier, betterdrained, alluvial soils, but unfortunately, almost all riparian forests that once covered these fertile soils have been cleared for agronomic crop production. Typically, only one soil nutrient must be added to native pecan groves- nitrogen. Zinc deficiency, common in southern states (Sparks, 1976), is rarely a problem in the north.

Pest control technologies, developed in southern pecan-producing states, have been adapted for northern growing conditions (Reid, 1988). Primary pests of northern pecans include pecan nut casebearer [A crobasis nuxvorella Neunzig], pecan weevil [Curculio caryae (H orn)], and pecan scab [C ladosporium caryi genum (EII. et Lang.) Gottwald]. These pests can be controlled with three to four pesticide applications per year (Reid and Eikenbary, 1991).

To prevent soil erosion during flooding events, grasses and forbs are allowed to grow in nativegroves. Growers often utilize this groundcover for livestock grazing, primarily beef cattle. Shortly before harvest season, livestock are removed from the grove; the groundcover is mowed; and the entire grove floor is raked clean of sticks, manure, and debris. The mechanical nutharvesting equipment used in native groves is designed to pick up nuts from a well-maintained groundcover.

N orthern native pecans grown under a complete management program

Table 2. $\mathrm{N}$ ut weight, percent kernel, maturity date, flowering type, and location of origin of important northern pecan cultivars ( $28.35 \mathrm{~g}=1.0 \mathrm{oz})$.

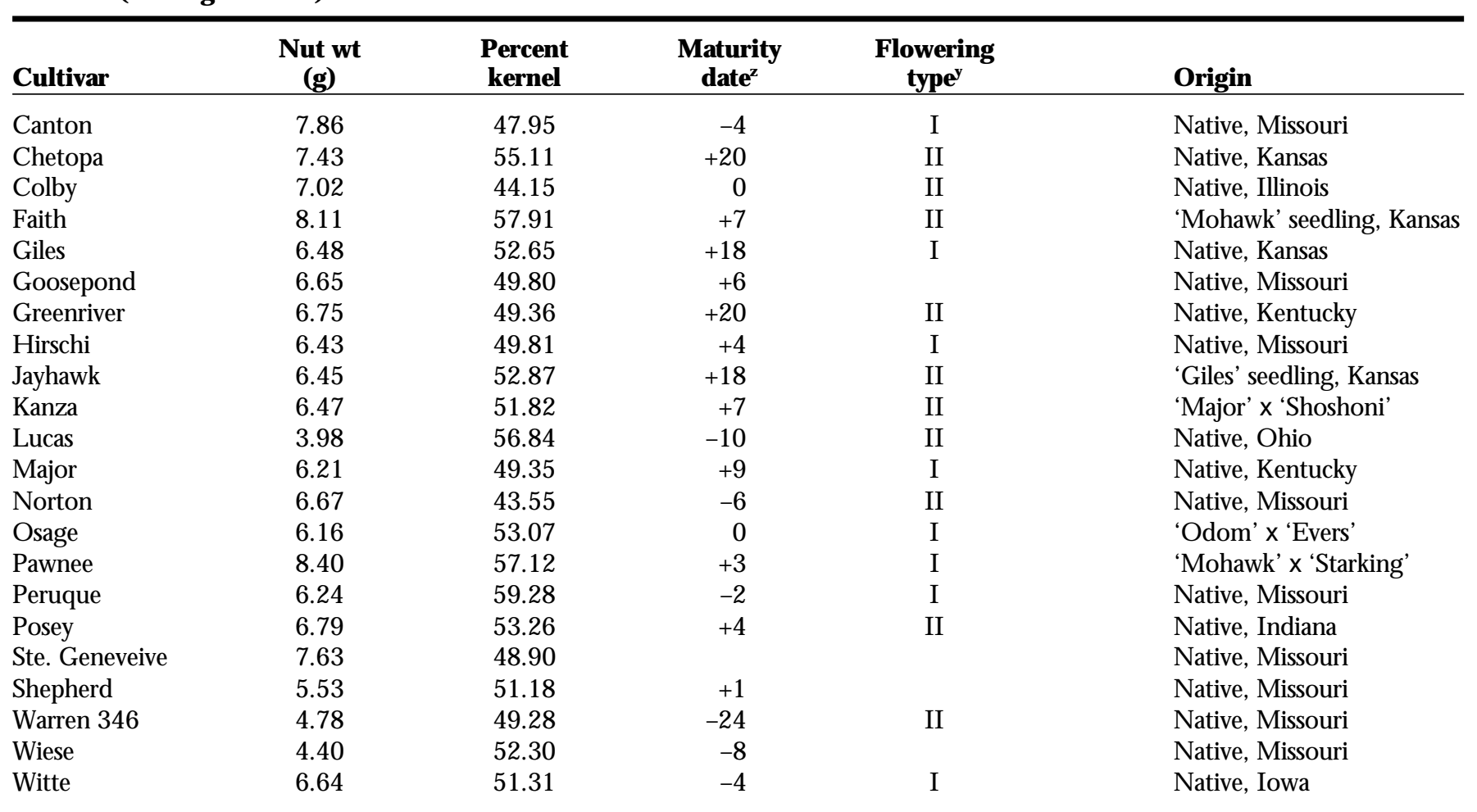

zD ays before (-) or after ( + ) 'C olby'. The average ripening date for 'C olby' is 25 Sept. in Chetopa, Kan. and 28 Sept. in Columbia, M o.

y| = protandrous, $\mathrm{II}=$ protogynous. 
can average over $1120 \mathrm{~kg} \cdot \mathrm{ha}^{-1}$ (1000 lb/ acre) (Reid, 1999b), a yield that rivals that of the best native groves in Texas (Stein and M CEachern, 1993). H owever, grower profitsfrom themanagement of northern native groves can be greater than that of native groves in southern states. Northern natives require fewer pesticide applications per year (see section below), lowering production costs. In addition, shellers pay higher pricesfor the high-quality, highpercent kernel, native nuts produced in northern pecan states (Table 1). Commercial production of northern native pecans is currently confined to three states: Kansas, M issouri, and I Ilinois. I n other northern states, native pecans are harvested by hand for home consumption.

\section{Climatic influences}

$\mathrm{N}$ orthern pecan trees are adapted to the continental climate of the central U nited States. Cold winters and hot summerscharacterizethisclimaticzone. $\mathrm{N}$ orthern pecans are frequently subjected to temperatures that drop to -30 ${ }^{\circ} \mathrm{C}\left(-22^{\circ} \mathrm{F}\right)$ during the winter. In sharp contrast, summer temperaturescan soar to over $38^{\circ} \mathrm{C}\left(100^{\circ} \mathrm{F}\right)$ during the day and never drop below $22^{\circ} \mathrm{C}\left(70^{\circ} \mathrm{F}\right)$ at night. The frost-free growing season in northern pecan states ranges from 155 to $200 \mathrm{~d}$. These climatic conditions significantly affect all aspects of pecan culture and management in the north.

Cold hardiness and early fruit maturity are generally recognized as attributes of northern pecans. It often is assumed that these two characteristics are linked. $\mathrm{H}$ owever, two early-ripening cultivars, ' $O$ sage' and 'Pawnee', both suffer significant shoot death during test winters. In contrast, 'Stuart' is cold hardy but the fruit will not ripen before the average date of first fall freeze in southeastern Kansas. Ripening date is controlled genetically but apparently modified by warm spring temperatures (Sparks, 1989). The production of pecansin northern statesisconfined to the central U nited States where sufficient heat is available to ripen nuts properly.

Climatealso playsasignificant role in pecan pest management. A shorter growing season means fewer generations per year of many important insect pests. In southern states, hickory shuckworm [Cydia caryana (Fitch)] minespecan shucksduring kernel deposition, causing a reduction in kernel quality. The very early nut maturity of pecansadapted to thenorth rendersthis pest inconsequential (Reid and Eikenbary, 1991). N orthern pecans fill their kernels before shuckworm larvae can cut off the supply of assimilates to the fruit. In contrast, early ripening increases susceptibility to the pecan weevil ( $\mathrm{H}$ arris, 1976). Early-ripening cultivars present emerging weevils with oviposition sites sooner than later-ripening cultivars and often become the favorite targets of this crop-destroying pest. As a consequence, northern pecan producers must work diligently to control pecan weevil but can largely ignore the hickory shuckworm.

The pecan aphid complex [M onelliopsis pecanis Bissell, M onellia caryella (Fitch), and Melanocallis caryaefoliae ( $D$ avis) ] presents a significant threat to commercial pecan orchards in southwestern and southeastern pecan orchards and often requires chemical control (D utcher, 1999). In contrast, a shorter growing season and a rich diversity of aphid predators keep indigenous aphid populations under control in northern native groves (D inkinset al., 1994; R eid et al., 1999).

The native pecans produced in northern states are known for their high quality, light kernel color, and high shelling percentage. The high quality of nuts grown in the north is directly related to the cool temperatures under which they ripen. $\mathrm{H}$ igh temperatures darken kernel color and hasten the development of rancidity (Sims, 1994). In northern pecan states, temperatures during harvest season average $13^{\circ} \mathrm{C}(55$ $\left.{ }^{\circ} \mathrm{F}\right)$ and dip below freezing at night. These conditions provide an excellent environment for on-farm storage of the crop. D uring years of inclement weather, cold winters allow northern growers to harvest their crop into $M$ arch while avoiding appreciable loss in nut quality. In addition to having excellent kernel color, northern native pecans generally produce a higher percent of edible kernel than their southern counterparts (Grauke et al., 1991). These quality factors result in shellers paying higher prices for northern pecans (T able 1 ).

\section{Northern pecan cultivars}

N orthern pecan cultivars are often characterized as producing small, hardshelled nuts on trees that are slow to bear, and low yielding (Sparks, 1992). $\mathrm{H}$ owever, these generalizations paint an inaccurate picture of the wide diversity of northern pecans currently avail- able to growers (T able 2). M ost northern cultivarsoriginated asselectionsfrom thewild. O ver theyears, northern growershave had theopportunity to evaluate a large number of naturally occurring pecan seedlings in their native stands. Trees that are productive, produce above-averagesized nuts, and shell well areoften propagated and named. G rowers freely share their selections and develop their own informal cultivar trials. With time, a selection that performs well for several growers becomes more widely propagated and becomes recognized as a cultivar.

Although large pecan cultivars [ $>9$ $\mathrm{g}(0.32 \mathrm{oz}) / \mathrm{nut}]$ can not mature their fruit in the north, several moderatesized cultivars [ 6 to $8 \mathrm{~g},(0.21$ to 0.28 oz) \} offer northern producers opportunitiesto grow a very marketable product (Table 2). When growers market pecan kernels directly to the consumer, they find that quality and flavor are far more important to the consumer than kernel size. Although several northern cultivars are thick shelled (e.g., 'Colby' and 'N orton'), other cultivars have thin or paper shells(e.g., 'Lucas' and 'Peruque'). The precocity of 'Colby', 'Giles', ' $\mathrm{H}$ irschi', and 'Peruque' is equal to that of precocious southern cultivars (Reid, 1992). In terms of yield, northern cultivars can overproduce like their southern counterparts and therefore require fruit thinning to ensure good nut quality during years of heavy crops (Smith et al., 1993).

Cultivar preferences of northern growers vary with location, although several cultivars have gained the attention of growers across the entire region. Two recent releases from the USDA pecan breeding program, 'Pawnee' and 'Kanza', havebeen widelygrafted. 'Pawnee' has the largest nut that can consistently mature nuts in the north but often suffers bud and limb injuryduring cold winters. 'Kanza' produces a medium-sized nut with outstanding kernel and shelling characteristics. The proven cold hardiness of ' $K$ anza' has made this cultivar thenumber onechoicefor grafting in northern groves. 'Peruque', 'Colby', and 'Posey' are popular standard cultivars that are still propagated across the northern pecan region.

$\mathrm{N}$ ew regional cultivarsoffer northern growers opportunities for even greater cultivar choice. 'C hetopa', 'Faith', and 'J ayhawk' arerecentlynamed cultivars that are gaining in popularity among growers in southern Kansas. 
'Faith', a seedling of ' $M$ ohawk', looks similar to 'Pawnee' but ripens 3 to $4 \mathrm{~d}$ later and has shown greater scab resistance than 'Pawnee'. 'Chetopa' and 'Jayhawk' are consistent producers of high quality, medium-sized nuts. 'Goosepond' is a recently discovered seedling from Brunswick, Mo. that promises to provide good nut size for growersin northern M issouri. Although not widely propagated, 'Warren 346' deserves special attention because of it ability to ripen fruits by mid-September in aclimatethat providesonly 155 frostfree days. Although this cultivar has a small nut, 'Warren 346' could benefit the entire pecan industry by serving as a source of genes for early ripening and cold hardiness.

\section{Future developments}

The pecan industry in the north will continue to grow as landowners discover the potential for profits from native trees. Thisis especially true in the Central States where northern pecans offer a profitable alternative for struggling, row-crop farmersfaced with record low commodity prices. $\mathrm{N}$ ative pecan management is often the starting point of a new pecan venture becausegrowers can realizeincome from wood sales and a modest nut crop during their first year of operation. In most cases, growers who become successful with native pecans will establish additional new orchards of trees grafted to northern cultivars. Theseorchardsaregenerally small in sizeand designed to fill gapsin native groves. Growers that develop their own retail market have a greater incentive to plant new orchards of northern cultivars - the ability to deliver a more uniform (i.e., single cultivar) product to their customers.

\section{Literature cited}

Dinkins, R.L., W.L. Tedders, and W. Reid. 1994. Predaceous neuropterans in Kansas and Georgia pecan trees. J. Entomol. Sci. 29:165-175.

D utcher, J.D. 1999. M anaging pecan aphids, p. 62-65. In: D. M cCraw, E.H. D ean, and B.W. Wood (eds.). Pecan industry: C urrent situation and future challenges. 3rd $\mathrm{N}$ atl. Pecan Wkshp. Proc. U SD A-ARS, 1998-04.

Grauke, L.J., B.W. Wood, and J.A. Payne. 1991. The U SD A pecan provenance study: Collecting pecans from Illinois to 0 axaca. Proc. Texas Pecan Grow. Assn. 67:35-39.

H arris, M .K. 1976. Pecan weevil adult emergence, onset of oviposition and larval emergencefrom thenut as affected by phenology of the pecan. J. Econ. Entomol. 69:167170.

$\mathrm{H}$ inrichs, H . 1958. H ow much room does a pecan treeneed? Proc. O kla. Pecan Growers Assn. 29:35-38.

N ational Agricultural StatisticsService. 1999. N oncitrus fruits and nuts: 1998 summary. Comm. Agr. D iv., Econ. Res. Serv., U SD A, July, FTS-286.

Peterson, J.K. 1990. Carya illinoensis (Wangenh.) K. Koch, Pecan, p. 205-210. In: R.M. Burns and B.H. H onkala (eds.). Silvics of North America. vol. 2. H ardwoods. U SD A For. Serv. Agr. H dbk. 654.

Reid, W. 1988. Principles of pecan insect management in Kansas. Annu. Rpt. N . N ut Growers Assn. 79:97-101.

Reid, W. 1992. The precocity of selected northern pecan cultivars. Fruit Var. J. 46:111-114.

Reid, W. 1995. Sustaining native pecan groves, p. 176-182. In: M.W. Smith, W. Reid, and B.W. Wood (eds.). Sustaining pecan production into the21st century. 2nd $N$ atl. Pecan Wkshp. Proc. U SDA-ARS 1995-3.

Reid, W. 1999a. H ealthy soil, healthy roots, healthy profits. Pecan S. 32(1):4.
Reid, W. 1999b. Native pecan management: Setting priorities. Pecan S. 32(5):1012.

Reid, W., R.L. D inkins, and W.L. Tedders. 1999. Predaceous Coccinellids in Georgia and Kansas pecan trees. J. Entomol. Sci. 34:363-366.

Reid, W. and R.D . E ikenbary. 1991. D eveloping low input management strategies for native pecan orchards, p. 69-76. In: B.W. Wood and J.A. Payne (eds.). Pecan husbandry: Challenges and opportunities. 1st $\mathrm{N}$ atl. Pecan Wkshp. Proc. U SD A-AR S-96.

Reid, W. and B. Olcott-Reid. 1985. Profits from native pecans. Annu. Rpt. N. N ut Growers Assn. 76:77-83.

Shreve, L.W. 1993. N ative pecan thinning. Sec. XIII, p. 7. In: G.R. M cE achern and L.A. Stein (eds.). Texas pecan handbook. Texas Agr. Ext. Serv. H ort. H dbk. 105. T exas A\& M U niv., College Station.

Sims, K.A. 1994. M echanization of postharvest pecan processing, p. 68-86. In:C.R. Santerre(ed.). Pecan technology. Chapman $\& \mathrm{H}$ all, N ew York.

Smith, M.W., W. Reid, B. Carroll, and B. Cheary. 1993. Mechanical fruit thinning influences fruit quality, yield, return fruit set, and cold injury of pecan. $\mathrm{H}$ ortScience 28:1081-1084.

Sparks, D. 1976. Zinc nutrition and the pecan-A review. Pecan S. 3(3):304-334.

Sparks, D . 1989. Predicting nut maturity of the pecan from heat units. $\mathrm{H}$ ortScience 24:454-455.

Sparks, D. 1992. Pecan cultivars, the orchard's foundation. Pecan Prod. Innovations, Publ., Watkinsville, Ga.

Stein, L.A. and G.R. M cEachern. 1993. $\mathrm{N}$ ative grove management. Sec. XIII, p. 15. In: G.R. M cE achern and L.A.Stein (eds.). Texas pecan handbook. Texas Agr. Ext. Serv. H ort. H dbk. 105. T exas A\& M U niv., College Station. 